\title{
ON THE WAY TO FOOD WELL-BEING. A CRITICAL ANALYSIS OF THE FOOD WELL- BEING CONCEPT AND THE POSSIBILITIES OF ITS EMPIRICAL VERIFICATION
}

\section{DOBROBIT POVEZANA S HRANOM. KRITIČKA ANALIZA KONCEPTA DOBROBITI POVEZANE S HRANOM I MOGUĆNOSTI NJEGOVE EMPIRIJSKE POTVRDE}

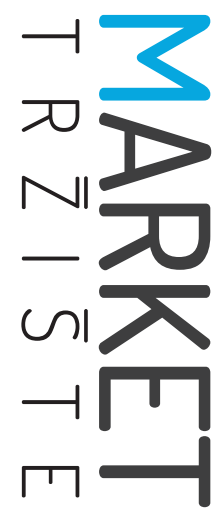

Vol. 32, Special Issue, 2020, pp. 31-48

UDK 2-442:005.935.3

D0l http://dx.doi.org/10.22598/mt/2020.32.spec-issue.31

Review

\begin{abstract}
Anna Rogala ${ }^{a}$, Renata Nestorowicz ${ }^{\text {b }}$ Ewa Jerzyk ${ }^{c}$
a Poznań University of Economics and Business, al. Niepodległości 10, 61-875 Poznań, POLAND, e-mail: anna.rogala@ue.poznan.pl

b Poznań University of Economics and Business, al. Niepodległości 10, 61-875 Poznań, POLAND, e-mail: renata.nestorowicz@ue.poznan.pl

c Poznań University of Economics and Business, al. Niepodległości 10, 61-875 Poznań, POLAND, e-mail: ewa.jerzyk@ue.poznan.pl
\end{abstract}

\section{Abstract}

Purpose - The purpose of this paper was to take a critical look at the FWB concept and the possibilities of its empirical verification, aimed at identifying limitations and difficulties in measurement.

Design/Methodology/Approach - The critical literature analysis is based on inductive reasoning and was conducted on two levels - the conceptual framework of FWB and empirical research in the FWB field.

Findings and implications - The interdisciplinarity of FWB conceptual models hinders their empirical verification. In the analysed studies, empirical measurements are characterized by fragmentation. The fact that researchers use various methods causes problems with comparing results and formulating universal conclusions or recommendations that contribute to increasing the level of FWB in terms of the individual or the society. Moreover, the issue of the shape of the FWB pinwheel needs to be clarified, e.g. individual issues should be included under a separate food (related) personality dimension.

Limitations - The analyses were based solely on the review of available literature and existing research, which

\section{Sažetak}

Svrha - Svrha je rada kritički sagledati koncept FBW (food well-being, dobrobit povezana s hranom) i mogućnosti njegove empirijske potvrde usmjerene utvrđivanju ograničenja i poteškoća u njegovu mjerenju.

Dizajn/metodologija/pristup - Kritička analiza literature zasniva se na induktivnom pristupu. Provedena je na dvjema razinama - na razini konceptualnog okvira FWB-a i na razini empirijskih istraživanja koncepta FWB-a.

Rezultati i implikacije - Interdisciplinarnost konceptualnih modela FWB-a ometa njihovu empirijsku potvrdu. $\mathrm{U}$ analiziranim studijama utvrđena je fragmentiranost empirijskih provjera. Primjena različitih metoda uzrokuje probleme usporedbe dobivenih rezultata, kao i formulacije općih zaključaka ili preporuka, koje bi pridonijele povećanju FBW-a na razini individue ili društva. U tom smislu bilo bi potrebno razjasniti potrebe uključene u "FWB zupčanik", primjerice, razviti posebnu dimenziju s hranom povezane osobnosti.

Ograničenja - Analize se temelje isključivo na analizi postojeće literature i istraživanjima koja su se uglavnom 
was conducted in most part from the perspective of one discipline. Primary empirical and interdisciplinary study is needed to explore the subject further.

Originality - To the best of authors' knowledge, no attempt has been made so far to analyse FWB in the presented approach, which would allow defining its conceptual limitations, the possibility of empirical verification or indicating research directions in individual dimensions of FWB.

Keywords - food well-being, well-being, eudaimonia, hedonism, food consumption provodila iz perspektive jedne znanstvene discipline. Za dublje razumijevanje ove teme potrebno je provesti interdisciplinarno empirijsko istraživanje.

Originalnost - Prema dosadašnjim saznanjima autorica, ne postoje pokušaji analize koncepta FWB-a poput ovdje opisanog pristupa, a koji bi omogućio definiranje njegovih konceptualnih ograničenja, empirijske potvrde ili budućih smjerova istraživanja pojedinačnih dimenzija FWB.

Ključne riječi - dobrobit hrane, blagostanje, eudaimonija, hedonizam, konzumacija hrane 


\section{FOOD IN GENERAL WELL-BEING}

Food and eating have always been and will continue to be a central part of the human experience: health, home and interpersonal relationships (Rozin, 2005; Block et al., 2011; Bublitz et al., 2013; Ares et al., 2014). However, so far food has not been appreciated in the concept of economic well-being, well-being in general, or the quality of life, with only a few researchers conducting analyses in this field (e.g. Grunert et al., 2007; Schnettler et al., 2013; Liu \& Grunert, 2020). Objective variables of well-being in relation to the specifics of the food market, such as expenditure on food, health, or food consumed outside of home, do not explain the concept of well-being as a subjective feeling of happiness, which is also determined by subjective variables, such as satisfaction with sharing food, not wasting food, or consumption of personalized food. For this reason, during these dynamic social changes, the virtualization of life and growing concerns about the future, we ought to take on the challenge of learning about the role of food and nutrition in relation to happiness and quality of life at the individual and collective level. The importance and the role of food in assessing well-being has changed over the years, the same way the perception of well-being as a measure of people's development, quality of life and happiness has (Stiglitz, Sen \& Fitoussi, 2013; Diener \& Suh, 1997; Diener \& Ryan, 2009). Initially, the measures of economic development potential, identified by economic growth (e.g. gross domestic product, net national product), were used for the assessment. With the emergence of negative effects of economic growth, there has been a growing awareness of the need for other measures of well-being that would take into account social and environmental costs (Cieślik, 2008).

Measuring the quality of life using extended indicators of social well-being accentuates problems related to food and nutrition, as well as sustainable development and globalization, such as the availability and the level of nutritional needs, calories consumed, life expectancy, and overall health (Garbicz, 2012). Well-being is related to the consumption of certain categories of food (organic, ethical, convenient, meat, fruit and vegetable consumption) and its impact on human health and the quality of the environment (Goetzke \& Spiller, 2014; Ding, Mullan \& Xavier, 2014; Zhong \& Mitchell, 2012; Bahl \& Milne, 2016; Batat et al., 2019; Bradford \& Grier, 2019). However, while new measures broaden our knowledge about well-being in individual countries, regions or cities, they mainly concern the area of consumption, relate only to the objective external conditions of the society, and omit the subjective assessment of the quality of life and the level of consumer happiness. Therefore, a wider, non-economic view of well-being, perceived as happiness and satisfaction with the quality of life from the perspective of the individual, is necessary. The concept of well-being extended by a non-material dimension in social sciences is referred to as well-being (WB) or happiness, and in economic sciences is treated as subjective well-being.

In research on well-being, two research perspectives distinguished on the basis of theoretical and philosophical assumptions emerge: a hedonistic and eudaimonistic one (Cornil \& Chandon, 2016a). The hedonistic approach to well-being is subjective and focuses on achieving pleasure at a given moment, which then determines a person's happiness. The hedonistic vision of happiness assumes achieving pleasure and having positive experiences, in addition to experiencing low intensity of negative emotions and high satisfaction with life (Kahneman, Diener \& Schwarz, 1999). However, adopting a broader perspective makes many of the negative consequences of hedonism appear on the horizon over a longer period of time. It turns out that maintaining long-term pleasure can be difficult and dangerous - it can lead to the overuse of stimulants, excessive consumption of emotional products leading to various lifestyle diseases, and the habituation effect (Wnuk, 2013; Zhong \& Mitchell, 2012; Lee \& Ahn, 


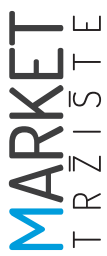

2016). The second understanding of well-being is derived from Aristotle's concept, where eudaimonia is defined as "human well-being or happiness, understood as a human life that is fulfilling and rich" (Russel, 2014). These two orientations - hedonistic and eudaimonistic - are referred to as subjective well-being and psychological well-being respectively. Subjective well-being (SWB) is equated with hedonistic values, while the well-being in the eudaimonistic concept has a more moralistic and normative nature and should be promoted as a way of eliminating various problems of the modern world, such as poverty or unjust societies (Carr, 2009; Ryff, 2017). The most promising approach is to integrate both well-being concepts and to treat the hedonistic and eudaimonistic schools as complementary. Despite the fact that these two approaches to well-being are based on different views of human nature, there is a lot of convergence between them and it is worth studying them at the same time to understand the essence of well-being (Deci \& Ryan, 2008).

Many well-being (WB) researchers recognize the key role of health and nutrition that goes beyond delivering nutrients as a result of nutritional decisions. For many years, the impact of nutrition on human well-being, the relationship between manifested consumer attitudes and the well-being of the individual, or the role of food and nutrition in human life have been in the area of theoretical and empirical inquiry from representatives of various disciplines. Until recently, they focused primarily on hedonistic aspects of consumption (Singhal, 2017; Bartels \& Onwezen, 2013; Galak, Kruger \& Loewenstain, 2013), but now more and more interest in eudaimonia and eudaimonistic motivation in this context is observed (Lui \& Fernando, 2018; Batat et al., 2019). Hence, the complexity and variety of functions that food fulfils in human life is a premise for modifying the perception of well-being and the need for an interdisciplinary approach to learning and understanding this important sphere of functioning of both societies and individuals. Therefore, the objective of this paper was to take a critical look at the FWB concept and the possibilities of its empirical verification, aimed at identifying its limitations and difficulties in measurement. The authors' intention was also to indicate the directions of further research in the context of the impact of food and the process of its consumption on human well-being.

\section{METHODOLOGY}

Taking into account the objectives of the paper, the authors used the critical literature review method, as this approach enables identifying strengths, weaknesses, contradictions and inconsistencies within different theoretical and empirical research works in the examined field (Paré et al., 2015). The analyses are based on inductive reasoning, and were conducted on two levels - the conceptual framework of FWB and empirical research in the FWB field. The content analysis was applied (Grant \& Booth, 2009) in identifying the contribution of papers to FWB theory.

To the best of the authors' knowledge, no attempt has been made so far to analyse FWB in the presented approach, which would allow for defining its conceptual limitations, the possibility of empirical verification or indicating research directions in individual dimensions of FWB. This approach involves important cognitive values.

In the first stage of the work, an analysis of peer-reviewed academic articles from the fields of consumer behaviours, psychology and sociology was conducted (Table 1). In searching for the texts dealing with the FWB concept, the authors conducted a preliminary research of the content of databases indexing scientific articles, such as Scopus, ProQuest Central, JSTOR and Web of Science. Articles containing the phrase "food well-being" were identified, while for theoretical analyses the results were limited only to those items in which the phrase appeared in the cumulative notation referring to FWB as a concept, and not the phenomenon of the influence 
TABLE 1: The procedure of selection of papers related to FWB

\section{Stages of procedure}

\section{Identification of scientific papers related to FWB:}

- Scopus (economics and management) - "Food well-being" in the title or keywords

- JSTOR (economics and management) - "Food well-being" in all fields

- ProQest - "Food well-being" in the title, abstract or keywords

- Wos Core Collection ('Business' and 'Economics') - "Food well-being" in the title

\section{Selection of papers and reduction of duplicate papers}

Criteria of selection:

- Language of publication - English

- FWB as a primary area of research

Full-texts included in the analysis 26

Source: own elaboration

of nutrition and food on human well-being. This limitation resulted from the purpose of the article. In addition, references were analysed in each of the articles found to determine whether there were other studies on FWB as a concept that were not listed in the search results, e.g. due to indexing of other keywords.

Out of the 26 articles read, five were theoretical, four combined theoretical aspects with empirical verification, and 17 were research papers. In the next phase, the selected documents were encoded and categorised. The results of content analysis were presented in two identified categories: FWB concept and FWB empirical research. In the course of further work within the theoretical plane, those studies which dealt with the phenomenon of the impact of food on well-being, but did not relate directly to the concept of FWB, were rejected. Finally, nine articles were qualified for the analysis of transformations of the FWB concept, including Block and others (2011) introducing the FWB concept. They will be discussed in the next part of this paper. In addition, within the empirical plane, 21 articles presenting research results on the FWB concept and its components were qualified for analysis. The comparison of research directions and methods used will be presented later in the text.

\section{MODIFICATIONS OF FOOD WELL-BEING CONCEPTUAL FRAMEWORK}

The idea of food well-being (FWB) appeared in scientific discussions in 2009 during the Transformative Consumer Research (TCR) conference, and was conceptualized two years later in the work of Block and others (2011, p. 6), who defined FWB as "positive psychological, physical, emotional, and social relationship with food at both the individual and societal level". The concept is based on changing the approach to food and the nutrition process from health-oriented to being focused on the well-being of the individual. This means that instead of a paternalistic focus on limitations and restrictions, it is necessary to adopt a consumer-oriented approach, emphasizing positive aspects resulting from consumption, presenting a more holistic understanding of the importance of food and nutrition for human well-being, including shaping the right attitudes and behaviours.

As a part of the FWB concept developed by Block and others (2011), the areas of key importance were food availability, food policy, food socialization, food literacy and food marketing, forming the so-called FWB pinwheel. In each 
TABLE 2: Factors influencing FWB

\begin{tabular}{|c|c|c|}
\hline $\begin{array}{l}\text { Level } \\
\text { Domain }\end{array}$ & Societal level & Individual level \\
\hline Food availability & $\begin{array}{l}\text { diversity, supply chain, profitability, } \\
\text { economics, food technology }\end{array}$ & accessibility, variety, availability \\
\hline Food policy & $\begin{array}{l}\text { agriculture policy, food safety policy, } \\
\text { nutrition policy, labelling policy }\end{array}$ & $\begin{array}{l}\text { calorie intake, disease, personal } \\
\text { beliefs }\end{array}$ \\
\hline Food socialization & media, culture, sub-culture & parenting, family, meals, peers \\
\hline Food literacy & education, guidelines, campaigns & $\begin{array}{l}\text { tools, heuristics, procedures, } \\
\text { techniques }\end{array}$ \\
\hline Food marketing & $\begin{array}{l}\text { marketing-mix, } \\
\text { targeting, positioning }\end{array}$ & $\begin{array}{l}\text { consumptions, cognitions, } \\
\text { emotions }\end{array}$ \\
\hline
\end{tabular}

Source: own elaboration based on Block et. al (2011).

of the areas, factors affecting attitudes and behaviour related to nutrition were identified and then considered in two dimensions - societal and individual (Table 2).

The presented approach differs from the previous ones referring to the food in the context of health relationship (e.g. Adriaanse et al., 2011; Goetzke et al., 2014), and treat food-related welfare issues selectively (e.g. Kim et al., 2013; Reeves et al., 2013). The key difference is mainly a result of the holistic approach to the analysed issue, with a strong emphasis on its interdisciplinarity, and pointing to different ways of influencing consumers when it comes to FWB. The proposed concept of Block and others (2011) was an inspiration for other researchers who developed the original concept or proposed alternative approaches in their conceptual and empirical works. The publication, which is the starting point of the conducted analyses, had 279 citations (according to Google Scholar).

The list of works treating FWB as a concept and containing its development is presented in Table 3. The discussion will be presented in a chronological order to show the development of the concept and interest in its individual components from a dynamic perspective.

Bublitz and others (2011) treat consumer FWB as a continuum and seek the possibility of measuring it in relation to the individual, thus expanding the individual FWB analysis. They believe consumers move along the continuum from low to high levels of FBW, making incremental progress along the way, which strengthens their faith in their own abilities and prompts them to make larger, more ambitious changes. They argue that determining individual's place on the FWB continuum and the readiness and ability to change is necessary not only to determine consumer's approach to food, but also to indicate ways in which consumers can be encouraged to adopt more aware, well-being-oriented consumer behaviours.

To determine where the consumer is on the continuum, the authors propose analysing five key areas: social influences, economic factors, food literacy, emotional knowledge, and physical and psychological traits, while also taking into account deliberative and automatic influences on food decision-making (Bublitz et al., 
TABLE 3: Modifications of the FWB concept (2011-2019)

\begin{tabular}{|c|c|c|c|}
\hline $\begin{array}{l}\text { Type of } \\
\text { contribution }\end{array}$ & $\begin{array}{l}\text { Perspective } \\
\text { of analyses }\end{array}$ & Author, year & $\begin{array}{l}\text { The differentiator in the } \\
\text { approach to the FWB concept }\end{array}$ \\
\hline \multirow{4}{*}{ Theoretical } & \multirow{3}{*}{ Individual } & Bublitz et al., 2011 & Consumer's FWB as continuum \\
\hline & & Bublitz et al., 2013 & $\begin{array}{l}\text { Advancement on consumer's FWB } \\
\text { continuum }\end{array}$ \\
\hline & & Batat et al., 2019 & $\begin{array}{l}\text { Experiental Pleasure of Food (EPF) } \\
\text { as an extension of FWB }\end{array}$ \\
\hline & Individual, society & Bublitz et al., 2019 & FWB in hunger \\
\hline \multirow{4}{*}{$\begin{array}{l}\text { Theoretical } \\
\text { plus empirical } \\
\text { implementation }\end{array}$} & \multirow[t]{2}{*}{ Individual } & $\begin{array}{l}\text { Manohar \& } \\
\text { Rehman, } 2018\end{array}$ & $\begin{array}{l}\text { FWB model extension with Food } \\
\text { Perception dimension }\end{array}$ \\
\hline & & Mugel et al., 2019 & FWB as an eudaimonic experience \\
\hline & Society, individual & Gartaula et al., 2017 & $\begin{array}{l}\text { FWB as a state (agrarian } \\
\text { perspective) }\end{array}$ \\
\hline & Individual, family & Voola et al., 2018 & FWB in poverty \\
\hline
\end{tabular}

Source: own elaboration

2011). The tool that allows measuring the FWB level of an individual is in this case perceived as a motivating instrument, enabling consumers to take care of well-being by indicating the current state, but also helping to set rationally defined, measurable and, above all, achievable nutrition goals. Thanks to their implementation, they gain a sense of agency and motivation in implementing subsequent changes. The authors consider the possibilities of influencing consumers and motivating them to make progress on the FWB path (including healthier food choices), while stressing that celebrating even small successes in this area is crucial from the point of view of achieving the goals.

The development of the FWB concept as a continuum is presented in the paper by Bublitz and others (2013). As in the previous case, here too the focus was on analysing the issue from the perspective of the individual, in particular referring to two aspects:

- The usefulness of consumer goals, motivation and readiness to change awareness in understanding consumer preparedness to advance FWB;
- The usage of cognitive and emotional information guiding food choices in advancing consumer's FWB.

The authors divide food-related goals into functional, symbolic and hedonic (Bublitz et al., 2013). Functional goals refer to activities related to improving health or reducing the risk of getting sick, so they are preventive or promote specific eating behaviour. In turn, symbolic goals relate to food as a social process and are associated with the creation of social bonds as a result of eating together or using a specific diet to adhere to or remain within social norms. In contrast, hedonic goals refer to gustatory pleasure and perception of well-being inherent in the experience of consuming food. The FWB concept does not exclude hedonistic goals as being an important part of positive food attitudes, but rather points to the need to skilfully balance health-oriented consumer needs with those that relate to pleasure.

Understanding the goals that consumers achieve as a part of their nutritional decisions is key from the point of view of using the right motivators and incentives to contribute to in- 


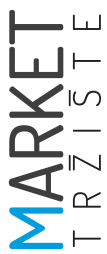

creasing the FWB level of the individual. To obtain a positive change in consumer behaviour in the context of FWB, it was proposed to use the Stages of Change Model, identifying elements of food literacy, emotional knowledge, social environment, self-reevaluation, social liberation, counter-conditioning, helping relationships, reinforcement, willpower and stimulus controls. In addition, the need to develop a tool to measure the impact of small changes in lifestyle and consumption habits, deliberatively or automatically affecting activities undertaken on the way to achieving a high FWB level, was raised. Both automatic and deliberative influences on food decision making can take the form of cognitive and emotional information, as well as internal and external ones. The awareness of the discussed dependencies and their impact on individual's progress on the FWB continuum is necessary for undertaking actions aimed at stimulating attitudes and behaviours raising the FWB level of individuals as well as entire societies.

In the work of Gartaula and others (2017), FWB is analysed from an agrarian perspective and does not refer directly to the FWB concept initiated by Block and others (2011). The text assumes that FWB is a "state where people are able to produce, choose, and consume food that is socially, culturally, ecologically appropriate and calorically, nutritionally, and subjectively satisfying" (p. 576). In this approach, FWB is a concept related to food availability, food entitlement and livelihood and food sovereignty approaches, focusing more on analyses conducted from the perspective of smaller and larger groups or communities, not individuals. The framework proposed by the authors of FWB consists of aspects which are objective (food security), subjective (food sovereignty) and relational (social wellbeing). Although the perspective adopted by the authors differs from those described so far, it is a significant complement to the analyses in FWB domains such as food availability and food policy, an approach relatively rarely undertaken as a part of the research on the FWB concept. For this reason, it was decided to include it in the discussed list.
Manohar and Rehman (2018) analysed components of the FWB model of Block and others (2011) in relation to packaged functional foods consumption. Factors related to food perception were indicated as particularly important, proposing an extended model of FWB, taking into account this dimension. According to the authors, food perception refers to the notion that healthier foods are also tastier. In this group of factors, aspects such as taste, different consumption forms, or the idea that it is not the sick man's propensity to consume on a regular basis (frequency), were included. Food perception, along with other elements of FWB, is expected to influence consumers' shopping intentions.

The work of Voola and others (2018) focuses on the use of the FWB concept for people living in poverty. A novelty, compared to previous concepts, is to include not only individual and societal dimensions in the analysis of individual components of FWB, but familial as well. Based on research, authors point to four key elements of FWB in poverty. They are food availability, food policy, food socialization and food capability. Compared to FWB pinwheel of Block and others (2011), in the FWB in Poverty pinwheel, the elements of food literacy (included in the category of food capability) and food marketing have been removed, due to the limited ability to read and count respondents, and thus under no influence of marketing activities based on reading skills on behaviour of this group. In turn, greater importance was attached to the influence of families on FWB. Until now, they have been included only in one element of FWB - food socialization, while in the concept of FWB in Poverty familial level has become a dimension of analysis in each of the pinwheel components.

The research of Bublitz and others (2019) is also associated with the problem of food scarcity. In scientific papers, the FWB paradigm is treated as an integrated framework for understanding the relationship between food and well-being, but in most analyses it refers to people who have sufficient or abundant access to food. 
Meanwhile, the group of consumers experiencing hunger requires special attention, because due to the limited or no financial resources to satisfy consumer needs, they have very limited opportunities to raise their FWB level. As in the case of the initial FWB concept, the key elements were considered: food availability, food policy, food socialization, food literacy and food marketing. Food availability is divided into "affordable access" and "food to thrive" (Bublitz et al., 2019). The first aspect is related to providing affordable access to available food (in order to address systemic societal challenges), and the second aspect is to provide people experiencing hunger with access to nutritious food to thrive. The authors draw attention to another important direction of research related to the impact of both excess and shortage of food on the relationships of people with FWB. They state that regardless of the social or material situation, everyone should be able to shape their FWB, including the selection of healthy food options, using available means and solutions.

Another study on the FWB concept focuses on FWB in consumers' experiences and is based on the eudaimonic approach to well-being (Mugel et al., 2019). The conceptual model of FWB presented in the text includes various processes, meanings, contextual conditions and resulting moods and emotions. The processes in which FWB appears include consumers' emancipation, immersion in food experience, sharing the experience and sensory processes. Food consumption and the resulting sense of well-being are analysed in a holistic way, and therefore the experience is not only the result of the consumption of specific products, but all consumption-related activities. Adopting a eudaimonistic approach makes FWB not a static, but rather a dynamic, meaningful and complex experience consisting of various elements.

The work of Batat and others (2019) introduces the concept of experiential pleasure of food (EPF). It is based on the concepts of Epicurean pleasure in eating (EEP) (Cornil \& Chandon, 2016a, 2016b) and FWB (Block et al., 2011). EPF is defined as "the enduring cognitive (satisfaction) and emotional (i.e. delight) value consumers gain from savouring the multi-sensory, communal, and cultural meaning in food experiences", leading to greater consumer's wellbeing (Batat et al., 2019, p. 393). The EPF journey consists of three phases: contemplation (food sensory), connection (sociocultural appreciation and food-sharing) and creation (food symbolism and storytelling). The concept as a starting point takes the view that the pleasure of eating is the basis of well-being, which means that getting into pleasant sensations and physical states leads to greater mindfulness in experiencing consumption, and thus to choosing a healthier model of nutrition. Thus healthy eating habits, good for the well-being, cease to be associated with restrictions and sacrifices, and begin to be equated with pleasure. Therefore, the consumer does not focus on controlling the temptations associated with unhealthy food, but strives to improve well-being by achieving pleasure from food, treated with care and commitment. The weakness of the concept results from the assumption of a conscious learning process, which is accompanied by mindfulness and commitment, while in most cases nutrition decisions are made based on heuristics and automatism.

The analysis of previous scientific achievements leads to the conclusion that most authors accept the FWB concept developed by Block and others (2011), enriching it with more in-depth investigations within individual components. However, the vast majority of works deal with issues related to food availability or food socialization, to a lesser extent referring to other components of FWB.

\section{REVIEW OF PREVIOUS RESEARCH IN THE FIELD OF FWB}

Research in the field of FWB in relation to the individual has developed in two directions. On the one hand, FWB is treated as one of the com-

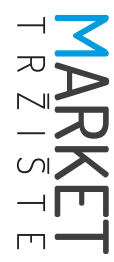


ponents of the subjective WB (SWB), while on the other hand, the components of FWB, the relationships between them, and the factors affecting FWB or its individual components are examined (Table 4).

One of the first to note the importance of food in shaping SWB was Grunert and others (2007). They noticed that among the components that shape SWB, other researchers mentioned marriage/family life, work, material standard of living/financial situation, leisure, friendships, health neighbourhood, religion and education. On the other hand, food was omitted as an important element of life, which affects the overall happiness and the well-being of the individual. In order to bridge this this gap and allow for it to be studied, Grunert and others (2007) created the SWFL (Satisfaction With Food-Related Life) scale. SWFL is a scale which, similarly to the SWLS (Satisfaction With Life Scale, Diener and others (1985)) refers to cognitive components, but at the FWB level, not the general WB level. If food is treated as one of the elements shaping general WB, then it is possible to examine the relationships between the respondents' claims in the field of SWFL and SWL at the cognitive level. Research in this area conducted by Grunert and others (2007) in eight European countries, by Schnettler and others (2013) in Chile, and Liu and Grunert (2020) in China, and showed statistically significant correlations.

Turning the research strictly to the FWB concept, attention should be paid to three aspects: the subject of the research, the methodology used, and the selection of respondents. These aspects will be discussed in this order.

Due to the subject scope, research in the field of FWB can be divided into 5 basic groups that focus on:

- general level of FWB - e.g. using the SWFL scale;

- factors affecting FWB - in terms of the FWB pinwheel;

- FWB components;

- dependencies between individual aspects of FWB;
- similarities and differences observed in the field of FWB in various social and national groups (e.g. Ares et al., 2016, Sulmont-Rossé et al., 2019).

Research on the factors affecting FWB (based on the FWB pinwheel proposed by Block and others (2011)) most often led to some modifications of this model. Based on their research among poor women in India, Voola and others (2018) added another level - familial, but limited the domains to four, mentioned earlier in this paper. Similarly, other researchers, such as Gartaula and others (2017) or Manohar and Rehman (2018), adapted or introduced a new FWB model, which was more appropriate in given cultural conditions in a selected social group. Sporadically, research which indicated the possibilities and strength of influence on FWB of individual elements of the pinwheel created by Block and others (2011) was carried out, especially at the societal level. These include research on the impact of marketing campaigns on FWB (Englund et al., 2020) or food socialization on the nutritional behaviour of adolescents and their well-being (De Rosis et al., 2019), but they relate to individual domains and narrower groups of consumers.

Research on FWB components may relate to the process of obtaining food, preparing a meal, eating together, sharing food, recycling leftovers, etc. One example of this approach is the research by Mugel, Gurviez and Decrop (2019). This component is particularly associated with food socialization and may gain importance in relation to sharing economy, or in regard to the 2020 pandemic. The second group of studies focusing on the FWB core are research on consumers' perception of wellbeing in a food-related context (Hémar-Nicolas \& Ezan, 2019), associations with well-being in a food-related context (Ares et al., 2014), or consumer behaviours consistent with values they find relevant, such as: pleasure, health, safety, comfort, interpersonal relationships and sustainable consumption that affect the level of FWB. In this approach, researchers either used different scales corre- 
TABLE 4: Comparison of papers analysis in the field of FWB

\begin{tabular}{|c|c|}
\hline $\begin{array}{c}\text { Criterion of } \\
\text { analysis }\end{array}$ & Findings \\
\hline $\begin{array}{l}\text { Field of } \\
\text { research }\end{array}$ & $\begin{array}{l}\text { 1. general level of FWB - e.g. developing and using the SWFL scale: Grunert et } \\
\text { al. (2007), Schnettler et al. (2013), Liu \& Grunert (2020) } \\
\text { 2. factors affecting FWB - in terms of the FWB pinwheel: Gartaula et al. (2017), } \\
\text { Voola et al. (2018), Manohar \& Rehman (2018), De Rosis et al. (2019), Englund } \\
\text { et al. (2020) } \\
\text { 3. perception of wellbeing in a food-related context: Ares et al. (2013), Ares et al. } \\
\text { (2014), Mugel, Gurviez i Decrop (2019), Hémar-Nicolas \& Ezan (2019), Bodunrin } \\
\text { \& Stone (2019) } \\
\text { 4. dependencies between individual aspects of FWB: Cornil \& Chandon (2016b), } \\
\text { Mujcic \& Oswald (2016), Batat et al. (2017), Wahl et al. (2017), Landry et al. (2018), } \\
\text { Bradford \& Grier (2018) } \\
\text { 5. similarities and differences observed in the field of FWB in various social and } \\
\text { national groups: Ares et al. (2014), Ares et al. (2016), Sulmont-Rossé et al. (2019) }\end{array}$ \\
\hline Con & $\begin{array}{l}\text { The authors of the analysed papers took into account the circumstances of the } \\
\text { phenomena's occurrence. The context referred to both the country and the } \\
\text { respondents' social origin. The context of the research played an important role } \\
\text { even in the research that was expected to empirically test the FWB pinwheel. } \\
\text { The geographical scope of the research was diverse: } \\
\text { - regional, conducted in a specific social group: seniors in Pekin (Liu \& Grunert, } \\
\text { 2020), women from poor families in rural South India (Voola et al., 2018), } \\
\text { respondents aged } 15 \text { and } 18 \text { years in Toscania, Italy (De Rosis et al., 2019), } 13 \\
\text { African-American participants in a food detoxification program (Bradford \& } \\
\text { Grier, 2018), participants from the University of Konstanz (Wahl et al., 2017) } \\
\text { - regional - varied sample: the principal cities of southern Chile (Schnettler et al., } \\
\text { 2013), villages in Kaski district, Nepal (Gartaula et al., 2017), respondents with a } \\
\text { normal weight and with obesity from Quebec City, Canada (Landry et al., 2018) } \\
\text { - national - specific social group: French children aged 6-11 years (Hémar- } \\
\text { Nicolas \& Ezan, 2019) } \\
\text { - national - varied sample: Manohar \& Rehman (2018), Englund et al. (2020), } \\
\text { Mugel, Gurviez \& Decrop (2019), Ares et al. (2013), Mujcic \& Oswald (2016), } \\
\text { Cornil \& Chandon (2016a) } \\
\text { - international: Grunert et al. (2007), Ares et al. (2014), Ares et al. (2016), Sulmont- } \\
\text { Rossé et al. (2019) }\end{array}$ \\
\hline $\begin{array}{l}\text { Research } \\
\text { method }\end{array}$ & $\begin{array}{l}\text { The research conducted in the first and the last thematic group was mainly } \\
\text { quantitative. } \\
\text { The research on the perception of wellbeing in a food-related context was } \\
\text { qualitative research. } \\
\text { In the remaining thematic groups, the qualitative approach was dominant, but } \\
\text { quantitative methods were also used. }\end{array}$ \\
\hline Triangulation & $\begin{array}{l}\text { In } 5 \text { out of } 21 \text { analysed articles, the triangulation of research methods was used: } \\
\text { Grunert et al. (2007), Wahl et al. (2017), Mugel, Gurviez \& Decrop (2019), Englund } \\
\text { et al. (2020) }\end{array}$ \\
\hline
\end{tabular}

- regional, conducted in a specific social group: seniors in Pekin (Liu \& Grunert, 2020), women from poor families in rural South India (Voola et al., 2018), respondents aged 15 and 18 years in Toscania, Italy (De Rosis et al., 2019), 13 African-American participants in a food detoxification program (Bradford \& Grier, 2018), participants from the University of Konstanz (Wahl et al., 2017)

- regional - varied sample: the principal cities of southern Chile (Schnettler et al., 2013), villages in Kaski district, Nepal (Gartaula et al., 2017), respondents with a normal weight and with obesity from Quebec City, Canada (Landry et al., 2018)

- national - specific social group. French children aged 6-11 years (HémarNicolas \& Ezan, 2019)

- national - varied sample: Manohar \& Rehman (2018), Englund et al. (2020), Mugel, Gurviez \& Decrop (2019), Ares et al. (2013), Mujcic \& Oswald (2016), Cornil \& Chandon (2016a)

- international: Grunert et al. (2007), Ares et al. (2014), Ares et al. (2016), Sulmont- 


\begin{tabular}{|c|c|}
\hline $\begin{array}{l}\text { Criterion of } \\
\text { analysis }\end{array}$ & Findings \\
\hline & $\begin{array}{l}\text { The applied research methods influenced the selection of the sample. In most } \\
\text { cases the sampling was purposive. On the other hand, some researchers used: } \\
\text { - probability sampling, e.g. Mujcic \& Oswald (2016) } \\
\text { - quota sampling, e.g. Grunert et al. (2007), Schnettler et al. (2013), Ares et al. } \\
\text { (2016), Sulmont-Rossé et al. (2019) } \\
\text { - snowball technique, e.g. Mugel, Gurviez \& Decrop (2019). } \\
\text { The size of the study groups varied and ranged from: } \\
\text { - the smallest samples (a dozen or several dozen people) in qualitative research: } \\
\text { Voola et al. (2018), Gartaula et al. (2016), Englund et al. (2020), Mugel, Gurviez } \\
\text { \& Decrop (2019), Hémar-Nicolas \& Ezan (2019), Landry et al. (2018), Wahl et al. } \\
\text { (2017), Bradford \& Grier (2018) } \\
\text { - medium-sized samples (several hundred people) mainly in quantitative } \\
\text { research: Liu \& Grunert (2020), Schnettler et al. (2013), Manohar \& Rehman } \\
\text { (2018), Cornil \& Chandon (2015) } \\
\text { - samples with the size of a few to tens of thousands of people in international, } \\
\text { quantitative studies (Grunert et al., 2007, Ares et al., 2016, Sulmont-Rossé et al., } \\
\text { 2019), by cluster analysis (De Rosis et al., 2019), by Examined longitudinal food } \\
\text { diaries (2007, 2009, and 2013) in the Household, Income, and Labour Dynamics } \\
\text { in Australia Survey (Mujcic \&Oswald, 2016) }\end{array}$ \\
\hline Generalizability & $\begin{array}{l}\text { Concerning the methods used, the sampling methods, the highly contextual } \\
\text { nature of the research, and the area of research that is inextricably linked with } \\
\text { the national culture, the possibilities of generalizing the results are quite limited. }\end{array}$ \\
\hline
\end{tabular}

Source: own elaboration

sponding to individual values (Liu \& Grunert, 2020), or a scale that quite comprehensively relates to these values. An example of such a scale could be the Meaning of Food in Life Questionnaire (MFLQ), taking into account different dimensions (moral, sacred, health, social and aesthetic) of meaning that people derive from the relationship to food (Arbit, Ruby \& Rozin, 2017).

Considering the fact that the FWB concept deviates from food as health paradigm to food as well-being (Block et al., 2011), some researchers focused on examining the relationship between FWB and the pleasure of eating and eating healthy, or differences between EEP (Epicurean Eating Pleasure) and VEP (Visceral Eating Pleasure) (e.g. Cornil \& Chandon, 2016b; Landry et al., 2018). The relationships most frequently analysed on the basis of empirical data concerned the relationship between the selected FWB components and the declared FWB level, various food-related behaviours (e.g. applied diets, alternative food consumption (AFC) i.e. plantbased, organic and local diets, entomophagy) and the level of FWB, food-related behaviours and SWB (Mujcic \& Oswald, 2016).

Despite the efforts invested by various researchers, the FWB concept and its components have not been comprehensively verified. The research usually concerned only a fragment related to this issue. Researchers focused mainly on consumers' overall assessment of FWB, their perception of FWB, or analysed one or more components of FWB as defined by Block and others (2011), doing so mainly from the perspective of the individual. On the other hand, the research using the FWB pinwheel comprehensively was conducted in poor countries. The purpose of this research was to show the differences between factors relevant to FWB in affluent and poor countries.

In examining the FWB concept, researchers used both qualitative and quantitative meth- 
ods. Quantitative research included surveys, structured interviews, and panel surveys. Qualitative research encompasses an even greater variety of methods, including word associations, open-ended questions and free listing, photo elicitation, phenomenological interviews, focus groups and drawings, observations (e.g. in a feast), experiments, or the introspective analysis from the film "Eat, Pray, Love", where the consumption of food for pleasure was heavily practiced (Bodunrin \& Stone, 2019). In addition, personal diaries and the contents of online blogs, forums and websites were also analysed. The use of projection research techniques, photographs or drawings allowed researchers to take a deeper look at the problem under analysis than if they had only used declarative research. In most cases, the conducted research was exploratory, which implied the need to use qualitative research.

The third aspect that is worth paying attention to are the diverse groups of respondents and their recruitment. Groups of older people (e.g. Liu \& Grunert, 2020) and children (e.g. Hémar-Nicolas \& Ezan, 2019) were particularly popular. Some studies included only women, considered responsible for preparing meals in a given environment (Voola et al., 2018), while others were studies covering all households in a given country. In most cases the groups were small, which was due to the qualitative nature of the research, selected deliberately, using the snowball method.

\section{LIMITATIONS OF THE FWB CONCEPT AND ITS EMPIRICAL VERIFICATION}

Based on the analyses carried out in this paper, one can outline the limitations of the FWB concept developed by Block and others (2011), as well as the problems related to empirical research. The interdisciplinary nature of the FWB conceptual models hinders their empirical verification, because this requires extensive knowledge from various disciplines and fields - psychology, sociology, marketing, nutrition sciences, etc. In the analysed studies, the authors discuss the issues comprehensively, but do not explore each element sufficiently and empirical measurements based on the FWB concept are characterized by fragmentation. In addition, research concepts are often treated as conceptual models, which presents additional difficulties in analysing these phenomena.

The FWB model was limited to five dimensions, namely food availability, food policy, food socialization, food literacy and food marketing. In each of them, analyses were conducted at individual and societal level. However, the classification of factors into individual levels does not seem to be entirely accurate. For example, the dimension of food marketing at the individual level is as much of a factor as the effects of other conditions, largely related to the personality traits of the individual. In addition, factors listed at the individual level in various dimensions (e.g. food policy - personal beliefs, food marketing - emotions or cognitions) penetrate in every sphere of the FWB, and not only in those dimensions to which they have been qualified, which may cause difficulties in empirical verification of the whole concept.

Assuming that one's FWB depends on the impact of all the included dimensions and factors, it can be concluded that their list is cursory, incomplete and lacks consequences. For example, in the case of food literacy, issues related to the level of information or health competences that are significant from the point of view of purchasing decisions in the area of food and FWB were not included. In turn, food policy at the individual level is associated not only with the indicated factors, but also largely with the social, familial and material status of the individual, considering these are associated with both food socialization and food availability. The same is true for food literacy and food marketing on the individual level. Personality issues of the individual that significantly affect the sense of happiness or well-being, which Bublitz and others $(2011,2013)$ adress as being key in the

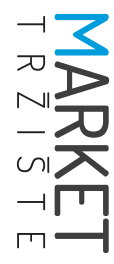


context of moving on the FWB continuum, have been classified into different groups within individual dimensions, and that, according to the authors, is not the right approach. One would expect greater insight and clarity in determining the role of the consumer, especially internal conditions (such as personality or attitudes) shaping the perception of happiness. Therefore, individual issues should be included under the separate food (related) personality dimension. According to the authors, the issue of the shape of the FWB pinwheel needs to be clarified, and researchers in various scientific disciplines have to be involved in this work.

By definition, the FWB concept is an interdisciplinary, comprehensive approach. On the one hand, that is its great advantage, but in the case of attempts at empirical verification this becomes a significant obstacle. The creators of the concept tried to comprehend the factors influencing FWB in the widest scope possible, also pointing to research directions, potential research problems and research questions. The problem, however, is so broad that it is difficult to include all these aspects in a larger sample, not to mention the issue of representativeness. As a result, the research concerns either a very small group of consumers or a small segment of FWB problems. The use of different methods and different approaches makes it difficult to combine these results into a coherent whole, to compare results in different groups, or to indicate changes that are taking place. The research is exploratory in nature and the effect is to "add" further fragmentary information, which do not enable creating a coherent image. Organising and ordering all results and identifying specific research gaps is lacking. Filling these gaps could organize the knowledge on the subject, help verify model assumptions, and build the foundation for further research.

The FWB research area is complex, requiring analysis of both objective indicators (e.g. availability of food, food expenditure) and subjective consumer feelings (satisfaction in the context of food). Only the combination of these two planes gives a chance for a comprehensive FWB analysis. However, while objective indicators can be obtained and assessed quite easily, the subjective examination of FWB is difficult. Firstly, each consumer can perceive and evaluate the events that shape FWB and the level of their satisfaction in relation to food completely differently. The most frequently used declarative methods do not guarantee that the consumer can consciously notice, recognize, name and admit to certain emotions, experiences or behaviours.

As for the results of research on FWB components, it should be noted that it may not be possible to precisely define universal FWB elements. The perceived FWB depends not so much on the specific attributes of food or activity associated with it, but on the fulfilment of expectations related to what a given consumer pays special attention to, what he is focused on, and what he considers important. The more the food allows the consumer to achieve the goals he has set (pleasure, safety, health), the higher the FWB level of a given consumer. If someone attaches importance to healthy eating, and then manages to maintain a diet consistent with his perception of healthy eating, he is more satisfied. If pleasure is a key value, then tasty food increases the individual's sense of FWB (Liu \& Grunert, 2020). It seems, therefore, that it is not appropriate to ask the question of what influences FWB more: hedonism or health, hedonism or eudaimonia. The more appropriate question seems to be how we can increase the FWB level depending on the segment of customers and different values they find important, in order to shape the individual well-being to have a positive impact on the social well-being.

The fact that researchers use various methods causes a problem when comparing results and formulating universal conclusions or recommendations that contribute to raising FWB in terms of the individual or society. In many cases the data obtained in the research is not universal, but rather a small contribution, a small fragment of a larger whole, valid only at a specific moment in a specific area. This data cannot be 
easily assembled into a larger whole, precisely because of the lack of research methods that could be used in different groups of respondents, regions or countries. Authors are well aware that new phenomena always require either the development of new methods or the adaptation of the existing ones and in the first phase of cognition the shortcomings of the primary research should be taken into account.

\section{CONCLUSIONS}

The analysis of the theoretical concepts of FWB and a review of research conducted in this area led to the unambiguous conclusion that this is an up-and-coming, promising area of interdisciplinary research. It requires further effort in theoretical and methodical work, especially in the context of ordering concepts and the structure of the model approach, which will not be hindered by different methodological techniques of researchers representing different disciplines of knowledge. We can anticipate that the initial enthusiasm surrounding the FWB concept and changing the food paradigm will soon lead to the creation of new, better FWB model attempts followed by new research ventures, although this will not be a simple task.

Following the analyses conducted in this paper, the authors agree with the areas for future re- search in the field of FWB, which were pointed out by Scott and Vallen (2019), especially those which relate to FWB conditions at the individual and group or society level, which are very promising. The authors consider understanding the individual behaviour of consumers, the determinants of their attitudes and purchasing decisions at the conscious and unconscious level, rational and irrational, taking into account their social, economic, and cultural characteristics, to be a key element in the process of increasing knowledge about FWB. However, other questions need to be answered, such as what means should be used to empower consumers and strength their food literacy to increase the level of their individual and societal well-being or how the socio-cultural settings impact the food product choices of an individual (Scott \& Vallen, 2019). Additionally, more research should be carried out for verifying the possibilities of promoting FWB through marketing activities to make consumers' food decisions healthier.

\section{Acknowledgement}

The project financed within the Regional Initiative for Excellence programme of the Polish Ministry of Science and Higher Education, years 2019-2022, grant no. 004/RID/2018/19, financing $3,000,000$ PLN.

\section{REFERENCES}

1. Adriaanse, M. A., Vinkers, C. D. W., De Ridder, D. T. D., Hox, J. J., \& De Wit, J. B. F. (2011). Do implementation intentions help to eat a healthy diet? A systematic review and meta-analysis of the empirical evidence. Appetite, 56(1), 183-193.

2. Arbit, N., Ruby, M., \& Rozin, P. (2017). Development and validation of the meaning of food in life questionnaire (MFLQ): Evidence for a new construct to explain eating behaviour. Food Quality and Preference, 59, 35-45.

3. Ares, G., De Saldamando, L., Giménez, A., \& Deliza, R. (2014). Food and wellbeing. Towards a consumer-based approach. Appetite, 74, 61-69.

4. Ares, G., Saldamando, L., Giménez, A., Claret, A., Cunha, L. M., Guerrero, L., Moura, A. P., Oliveira, D., Symoneaux, R., \& Deliza, R. (2015). Consumers' associations with wellbeing in a food-related context: A cross-cultural study. Food Quality and Preference, 40, Part B, 304-315.

5. Ares, G., Giménez, A., Vidal, L., Zhou, Y., Krystallis, A., Tsalis, G., Symoneaux, R., Cunha, L. M., de Moura, A. P., Claret, A., Guerrero, L., Cardello, A. V., Wright, A., Jefferies, L., Lloyd, M., Oliveira, D., 
\& Deliza, R. (2016). Do we all perceive food-related wellbeing in the same way? Results from an exploratory cross-cultural study. Food Quality \& Preference, 52, 62-73.

6. Bahl, S., Milne, G. R., Ross, S. M., Mick, D. G., Grier, S. A., Chugani, S. K., Chan, S. S., Gould, S., Cho, Y.-N., Dorsey, J. D., Schindler, R, M., Murdock, M. R., \& Boesen-Mariani, S. (2016). Mindfulness: Its Transformative Potential for Consumer, Societal, and Environmental Well-Being. Journal of Public Policy \& Marketing, 35(2), 198-210.

7. Bartels, J., \& Onwezen, M. C. (2014). Consumers' willingness to buy products with environmental and ethical claims: the roles of social representations and social identity, Social representations and social identity. International Journal of Consumer Studies, 38, 82-89.

8. Batat, W., Peter, P. C., Moscato, E. M., Castro, I. A., Chan, S., Chugani, S. K., \& Muldrow, A. F. (2019). The experiential pleasure of food: A savoring journey to food well-being. Journal of Business Research, 100(C), 392-399.

9. Block, L. G., Grier, S. A., Childers, T. L., Davis, B., Ebert, J. E. J., Kumanyika, S., Laczniak, R. N., Machin, J. E., Motley, C. M., Peracchio, L., Pettigrew, S., Scott, M., \&Van Ginkel Bieshaar, M. N. G. (2011). From nutrients to nurturance: A conceptual introduction to food well-being. Journal of Public Policy and Marketing, 30(1), 5-1.

10. Bodunrin, T. S., \& Stone, T. (2019). Consuming well-being and happiness through epicurean ingestion. Qualitative Market Research, 22(4), 595-607.

11. Bradford, T. W., \& Grier, S. (2019). Restricted pleasure for healthy eating and food well-being. Qualitative Market Research, 22(4), 557-569.

12. Bublitz M. G., Peracchio L. A., Andreasen A. R., Kees J., Kidwell B., Miller E. G., Motley C. M., Peter P. C., Rajagopal, P., Scott M. L., \& Vallen, B. (2011). The Quest for Eating Right: Advancing Food Well-being. Journal of Research for Consumers, 19(1), 1-12.

13. Bublitz, M. G., Peracchio, L. A., Andreasen, A. R., Kees, J., Kidwell, B., Miller, E. G., Motley, C. M., Peter, P. C., Rajagopal, P., Scott, M. L., \& Vallen, B. (2013). Promoting positive change: Advancing the food well-being paradigm. Journal of Business Research, 66(8), 1211-1218.

14. Bublitz, M. G., Hansen, J., Peracchio, L. A., \& Tussler, S. (2019). Hunger and Food Well-Being: Advancing Research and Practice. Journal of Public Policy and Marketing, 38(2), 136-153.

15. Carr, A. (2009). Psychologia pozytywna. Nauka o szczęściu i ludzkich siłach. Poznań: Zysk i S-ka.

16. Cieślik, E. (2008). Wybrane alternatywne sposoby mierzenia poziomu rozwoju gospodarczego. Equilibrium. Quarterly Journal Of Economics And Economic Policy, 1(1-2), 145-160.

17. Cornil, Y., \& Chandon, P. (2016a). Pleasure as an ally of healthy eating? Contrasting visceral and Epicurean eating pleasure and their association with portion size preference and wellbeing. Appetite, 104, 52-59.

18. Cornil, Y., \& Chandon, P. (2016b). Pleasure as a substitute for size: How multisensory imagery can make people happier with smaller food portions. Journal of Marketing Research, 53(5), 847-864.

19. Deci, E. L., \& Ryan, R. M. (2008). Hedonia, eudaimonia, and well-being: an introduction. Journal of Happiness Studies, 9, 1-11.

20. De Rosis, S., Pennucci, F., \& Seghieri, C. (2019). Segmenting Adolescents Around Social Influences on Their Eating Behavior: Findings From Italy. Social Marketing Quarterly, 25(4), 256-274.

21. Diener, E., Emmons, R. A., Larsen, R. J., \& Griffin, S. (1985). The satisfaction with life scale. Journal of Personality Assessment, 49, 71-75.

22. Diener, E., \& Ryan, K. (2009). Subjective Well-Being: A General Overview. South African Journal of Psychology, 39(4), 391-406.

23. Diener, E., \& Suh, E. (1997). Measuring quality of life: Economic, social, and subjective indicators. Social Indicators Research, 40(1-2), 189-216. 
24. Ding, T., Mullan, B., \& Xavier, K. (2014). Does subjective well-being predict health-enhancing behaviour? The example of fruit and vegetable consumption. British Food Journal, 116(4), 598-610.

25. Englund, T. R., Zhou, M., Hedrick, V. E., \& Kraak, V. I. (2020). How Branded Marketing and Media Campaigns Can Support a Healthy Diet and Food Well-Being for Americans: Evidence for 13 Campaigns in the United States. Journal of Nutrition Education and Behavior, 52(1), 87-95.

26. Galak, J., Kruger. J., \& Loewenstein, G. (2013). Slow Down! Insensitivity to Rate of Consumption Leads to Avoidable Satiation. Journal of Consumer Research, 39 (5), 993-1009.

27. Garbicz, M. (2012). Problemy rozwoju i zacofania ekonomicznego. Dlaczego jedne kraje sa biedne, podczas gdy inne sa bogate? Warsaw: Oficyna Wolters Kluwer.

28. Gartaula, H., Patel, K., Johnson, D., Devkota, R., Khadka, K., \& Chaudhary, P. (2017). From food security to food wellbeing: examining food security through the lens of food wellbeing in Nepal's rapidly changing agrarian landscape. Agriculture and Human Values, 34(3), 573-589.

29. Goetzke, B., Nitzko, S., \& Spiller, A. (2014). Consumption of organic and functional food. A matter of well-being and health? Appetite, 77, 96-105.

30. Goetzke, B., \& Spiller, A. (2014), Health-improving lifestyles of organic and functional food consumers, British Food Journal, 116(3), 510-526.

31. Grant, M. J., \& Booth, A. (2009). A typology of reviews: an analysis of 14 review types and associated methodologies. Health Information \& Libraries Journal, 26(2), 91-108.

32. Grunert, K. G., Dean, M., Raats, M. M., Nielsen, N. A., \& Lumbers, M. (2007). Food in Later Life Team. A measure of satisfaction with food-related life. Appetite, 49, 486-493.

33. Hémar-Nicolas, V., \& Ezan, P. (2019). How do children make sense of food well-being? Food for thought for responsible retailers. International Journal of Retail and Distribution Management, 47(6), 605-622.

34. Kahneman, D., Diener, E., \& Schwarz, N. (Eds.). (1999). Well-being: The foundations of hedonic psychology. New York, NY: Russell Sage Foundation.

35. Kim, M., Lee, C., Kim, W. G., \& Kim, J. (2013). Relationships between lifestyle of health and sustainability and healthy food choices for seniors. International Journal of Contemporary Hospitality Management, 25(4), 558-576.

36. Landry, M., Lemieux, S., Lapointe, A., Bédard, A., Bélanger-Gravel, A., Bégin, C., Provencher, V., \& Desroches, S. (2018). Is eating pleasure compatible with healthy eating? A qualitative study on Quebecers' perceptions. Appetite, 125, 537-547.

37. Lee M. S. W., \& Ahn, C. (2016). Anti-consumption, Materialism, and Consumer Well-being. Journal of Consumer Affairs, 50(1), 18-47.

38. Liu, R., \& Grunert, K. G., (2020). Satisfaction with food-related life and beliefs about food health, safety, freshness and taste among the elderly in China: A segmentation analysis. Food Quality and Preference, 79, 1-10.

39. Lui, P. P., \& Fernando, G. A. (2018). Development and initial validation of a multidimensional scale assessing subjective well-being: The Well-Being Scale (WeBS). Psychological Reports, 121(1), 135160.

40. Manohar, S., \& Rehman, V., (2018). Drivers to Nurturance: Application and Extension of FWB in India. Journal of International Food \& Agribusiness Marketing, 30(2), 132-155.

41. Mugel, O., Gurviez, P., \& Decrop, A. (2019). Eudaimonia Around the Kitchen: A Hermeneutic Approach to Understanding Food Well-Being in Consumers' Lived Experiences. Journal of Public Policy and Marketing, 38(2), 280-295.

42. Mujcic, R., \& Oswald, A. J. (2016). Evolution of Well-Being and Happiness After Increases in Consumption of Fruit and Vegetables. AJPH RESEARCH, 106(8), 1504-1510. 
43. Paré, G., Trudel, M. C., Jaana, M., \& Kitsiou, S. (2015). Synthesizing information systems knowledge: A typology of literature reviews. Information \& Management, 52(2), 183-199.

44. Reeves, S., Halsey, L. G., McMeel, Y., \& Huber, J. W. (2013). Breakfast habits, beliefs and measures of health and wellbeing in a nationally representative UK sample. Appetite, 60(1), 51-57.

45. Rozin, P. (2005). The Meaning of Food in Our Lives: A Cross-Cultural Perspective on Eating and Well-Being. Journal of Nutrition Education \& Behavior, 37, S107-S112.

46. Russell D. (2014) Eudaimonia. In A. C. Michalos (Ed.) Encyclopedia of Quality of Life and Well-Being Research. Dordrecht: Springer.

47. Ryff C. D. (2017). Eudaimonic well-being, inequality, and health: Recent findings and future directions. International Review of Economics, 64(2), 159-178.

48. Schnettler, B., Miranda, H., Sepúlveda, J., Denegri M., Mora M., Lobos, G., \& Grunert, K. G. (2013). Psychometric properties of the satisfaction with food-related life scale: Application in Southern Chile. Journal of Nutrition Education and Behavior, 45(5), 443-449

49. Scott, M. L., \& Vallen, B. (2019). Expanding the Lens of Food Well-Being: An Examination of Contemporary Marketing, Policy, and Practice with an Eye on the Future. Journal of Public Policy \& Marketing, 38(2), 127-135.

50. Singhal, N. (2017). A Study of Consumer Behavior Towards Organic Food and the Moderating Effects of Health Consciousness. IUP Journal of Marketing Management, 16(3), 45-79, Retrieved 11-03-2020 from http://search.ebscohost.com/login.aspx?direct=true\&db=bsu\&AN=124880564\&lang=pl\&site=bsi-live

51. Stiglitz, J. E., Sen, A., \& Fitoussi, J.-P. (2013). Błąd pomiaru. Dlaczego PKB nie wystarcza. Raport Komisji ds. Pomiaru Wydajności Ekonomicznej i Postępu Społecznego. Warsaw: PTE.

52. Sulmont-Rossé, C., Silva, A. P., Ares, G., van Zyl, H., McEwan, J. A., Kern, M., Drabek, R., \& Almli, V. L. (2019). A cross-cultural perspective on feeling good in the context of foods and beverages. Food Research International. 115, 292-301.

53. Voola, A. P., Voola, R., Wyllie, J., Carlson, J., \& Sridharan, S. (2018). Families and food: exploring food well-being in poverty. European Journal of Marketing, 52(12), 2423-2448.

54. Wahl, D. R., Villinger, K., König, L. M., Ziesemer, K., Schupp, H. T., \& Renner, B. (2017). Healthy food choices are happy food choices: Evidence from a real life sample using smartphone based assessments. Scientific Reports, 7, 17069.

55. Wnuk, M. (2013). Hedonizm, eudajmonia oraz przepływ/zaangażowanie jako trzy nurty badań nad szczęściem. Hygeia Public Health, 48(3), 285-288.

56. Zhong, J. Y., \& Mitchell, V. (2012). Does Consumer Well-Being Affect Hedonic Consumption? Psychology \& Marketing, 29(8), 583-594. 